\title{
Why Death Need Not Be "Reasonably Foreseeable"-The Proposed Legislative Response to Truchon and Gladu v Attorney General (Canada) and Attorney General (Quebec) [2019] QCCS 3792
}

\author{
Michaela Estelle Okninski $[$ D
}

Received: 27 October 2020 / Accepted: 6 January 2021 /Published online: 15 January 2021

(C) Journal of Bioethical Inquiry Pty Ltd. 2021

Keywords Law $\cdot$ Euthanasia $\cdot$ Physician assisted suicide

\section{Introduction}

Medical Assistance in Dying (MAID) has become an inescapable reality in Canada since the Supreme Court of Canada (SCC) declared in Carter v Canada (Attorney General) ([2015] 1 S.C.R. 331) (Carter) that the blanket prohibition on physician assisted dying was unconstitutional. Instead of prescribing the regulatory criteria to control the provision of MAID, the SCC invited the respective federal and provincial governments to establish the legislative framework (Carter, [127]). After months of deliberation, the Medical Assistance in Dying Act (MAID Act) (Criminal Code, R.S.C. (1985), c. C-46, ss 241.1-241.4, An Act to Amend the Criminal Code and to Make Related Amendments to Other Acts (Medical Assistance in Dying)) came into force on 17 June 2016.

The passing of the MAID Act failed to quell the controversies surrounding MAID. Shortly after it came into force, proceedings were once again initiated against the Attorney General of Canada, this time joined by the Attorney General of Quebec, on the grounds that selected eligibility criteria that restricted access to MAID were unconstitutional and inconsistent with the declaration issued in Carter (Truchon and Gladu v Attorney

\section{E. Okninski $(\bowtie)$}

Adelaide Law School, University of Adelaide, North Terrace, Adelaide 5005, Australia

e-mail: Michaela.okninski@adelaide.edu.au
General (Canada) and Attorney General (Quebec), [2019] QCCS 3792, [5]-[7]) (Truchon). This Recent Developments article will consider Baudouin J's judgment in, and the proposed legislative response to, Truchon. This development is worthy of discussion as removing the requirement that death occur within a defined period has significantly broadened the class of persons eligible to access MAID in Canada.

\section{Facts}

On September 11, 2019, the Superior Court of Quebec handed down its long-awaited judgment in Truchon. The applicants, Jean Truchon and Nicole Gladu, challenged the validity of s 241.2(2)(d) of the MAID Act and s 26(3) of Quebec's Act Respecting End of Life Care (CQLR, c. S32.0001) (ELC Act) which rendered them ineligible to access MAID. ${ }^{1}$ The impugned provisions under both statutes served to limit access to MAID on the basis of imminence (or not) of death. Section 241.2(2)(d) of the MAID Act provided that the person must have, amongst other things, ${ }^{2}$ a grievous and irremediable medical condition, which required that "their natural death has become reasonably foreseeable" (own emphasis). In Comparison, s 26(3) of the ELC Act explicated that the person had to be, subject to

\footnotetext{
${ }^{1}$ Mr Truchon suffered from spastic cerebral palsy with triparesis since birth and Ms Gladu suffered from poliomyelitis ([17], [51]-[52]). See paras [42]-[45] and [66]-[70], respectively, for discussion on $\mathrm{Mr}$ Truchon's and Ms Gladu's application for MAID.

${ }^{2}$ See MAID Act s 241.2(1), (2)(a)-(c).
} 
other criteria, "at the end of life" (own emphasis). These temporal restrictions formed the basis of the applicants' claim.

\section{Issues for Determination}

The applicants' contended that these requirements, which deemed them ineligible to access MAID, were invalid as they:

1. violated the principles set out in Carter; and

2. infringed their section 7 rights to life, liberty, and security of the person and their section 15 right to equality guaranteed by the Canadian Charter of Rights and Freedoms (Canada Act 1982 (U.K.), 1982, Sch B, c.11) (CCRF).

Thus, the issues for determination before the court were whether the impugned provisions:

- were inconsistent with the declaration issued in Carter; and

- infringed sections 7 and 15 of the $C C R F$ and, if so, whether the infringements were justified under $\mathrm{s} 1$ of the $C C R F$.

\section{Findings/Conclusion}

The court found in favour of the applicants. Consistent with the Court's approach, the following discussion will consider each jurisdiction separately.

\section{Federal Law}

First, in determining that the reasonable foreseeability of natural death requirement was inconsistent with Carter, Baudouin J stated that the declaration "should be construed as providing access to any person who meets the Supreme Court's clear requirements, whether or not death is reasonably foreseeable" [499].

Second, in concluding that the challenged provision infringed the applicants' s 7 right to life, Baudouin J observed that this requirement "exposes individuals such as Mr Truchon and Ms Gladu, to a heightened risk of death" [522]. In determining that their s 7 rights to

\footnotetext{
$\overline{{ }^{3} \text { See ELC Act s }} 26$ (1)-(6).
}

liberty and security of the person were violated, her Honour concluded that this criterion "directly interferes with their physical integrity, causes them physical and psychological pain and deprives them of the opportunity to make a fundamental decision that respects their personal dignity and integrity" [534].

Justice Baudouin turned to the objects of the provision to determine whether the infringement of rights was inconsistent with principles of fundamental justice. Finding that object was to protect vulnerable persons from ending their life in a moment of weakness [561]-[564], her Honour concluded that the provision was overbroad and grossly disproportionate to its object [574, 582], and indeed inconsistent with the principles of fundamental justice [587].

Her Honour further determined that the infringement of rights was not justified. The object of protecting vulnerable persons from ending their life in a moment of weakness, although pressing and substantial [601], was not the least drastic means available to achieve parliament's objective [617]-[618]. Moreover, the deleterious effects of the restriction on people in similar situations to the applicants were disproportionate to the expected benefits of the requirement that natural death be reasonably foreseeable [637]. This reasoning was based on the finding that physicians were capable of diligently assessing the capacity of patients who requested MAID and were able to identify vitiating factors such as coercion, external pressure, and suicidality [466, 619].

In concluding that the restriction infringed the right to equality, her Honour remarked that it created a distinction based on the type or nature of a disability which perpetuated prejudice and disadvantage for Mr Truchon and Ms Gladu [674]. Justice Baudouin articulated that the "type of physical disability, which does not have the effect of rendering their natural death reasonably foreseeable, thus prevents them from choosing their end of life, whereas other people just as physically disabled but whose death is close have that legal option" [663]. In determining that the infringement on the right to equality was not justified, the Court referred to its previous analysis and conclusion on this issue [685]-[690].

Provincial Law

In applying the same legal principles and reasons to the ELC Act, mutatis mutandis, it was concluded that the 
end of life criterion violated s 15 of the $C C R F$ and the infringement was not justified [705, 732]. Her Honour decided not to consider whether section 26(3) of the ELC Act infringed section 7 of the Canadian Charter of Rights and Freedoms [733].

\section{The Proposed Legislative Response}

The Court suspended the declaration of invalidity of $\mathrm{s}$ 241.2(2)(d) of the MAID Act and s 26(3) of the ELC Act for 10 months, until 11 July 2020 (Department of Justice 2020b). Although the declaration in Truchon was only in force in Quebec, the federal government committed to responding to the court's ruling by amending the MAID Act nationwide (Department of Justice 2020a). On February 24 2020, Bill C-7: An Act to Amend the Criminal Code (Medical Assistance in Dying), was introduced in parliament.

Bill C-7 seeks to repeal the requirement that a person's natural death be reasonably foreseeable. However, in recognition of the fact that removing this restriction could pave the way for persons with mental illness as the sole underlying condition to access MAID, Bill C-7 expressly states that "mental illness is not an illness, disease or disability," thus reinforcing the position that psychiatric conditions alone are not a basis to request MAID (cl 1(2)).

The Bill maintains a strong protective position proposing two different sets of safeguards depending on whether the person's natural death is reasonably foreseeable or not. The impetus behind this continued protective position was that greater care and protection were required for persons who were not at the end of life, which includes increasing the waiting period to receive MAID to 90 days (cl 1(3)). Furthermore, amendments were included to ensure that a specialist, expert in the area of the person's illness, is consulted and the person is informed of alternatives to MAID such as counselling and support services. ${ }^{4}$

Due to the unprecedented challenges and widespread disruptions caused by COVID-19, the court granted an extension to the federal government, suspending the declaration of invalidity for 5 months, until 18 December 2020 (Truchon and Gladu v Attorney General (Canada) and Attorney General (Quebec), [2020] QCCS 2019 [25]-[26]). The application for an extension

\footnotetext{
${ }^{4}$ See also Julia Nicol and Marlisa Tiedemann (2020).
}

was heard before Bachand J, who declared that authorized persons, who meet all the criteria to access MAID except s 241.2(2)(d) of the MAID Act, can apply to a court to receive judicial authorization to access MAID [28]. Bill C-7 passed the House of Commons on December 10, 2020 and was referred to the Standing Senate Committee on Legal and Constitutional Affairs on December 17, 2020. It, therefore, remains to be implemented and is still progressing through the federal parliament (LegisInfo 2020). In response to Truchon, Quebec simply removed the criterion that the person be at the end of life, which became operational on March 12, 2020 (Gouvernement du Québec 2020).

\section{Conclusion}

The impact of Carter continues to be felt throughout Canada. Removal of the requirement that the person be nearing death to access MAID has inevitably opened MAID up to a wider cohort of persons. This development may have broader appeal for jurisdictions where legalisation of physician-assisted dying is a live issue, as questions concerning eligibility often prove divisive. ${ }^{5}$ Whilst it is clear that this development will result in a wider pool of persons eligible to access MAID, what remains to be seen is just how wide the pool will become. This is a question for which only time can tell.

\section{References}

Department of Justice. 2020a. Government of Canada consults Canadians on medical assistance in dying. Government of Canada, January 13. https://www.canada.ca/en/departmentjustice/news/2020/01/government-of-canada-consultscanadians-on-medical-assistance-in-dying.html. Accessed January 06, 2021.

2020b. Proposed changes to Canada's medical assistance in dying legislation. Government of Canada, December 18. https://www.justice.gc.ca/eng/csj-sjc/pl/ad-am/index.html. Accessed September 10, 2020.

Gouvernement du Québec. 2020. Medical aid in dying. Quebec, March 12. (Web Page, 10 September 2020) https://www. quebec.ca/en/health/health-system-and-services/end-of-lifecare/medical-aid-in-dying/. September 10, 2020.

LegisInfo. 2020. House Government Bill: C-7 An Act to Amend the Criminal Code (Medical Assistance in Dying).

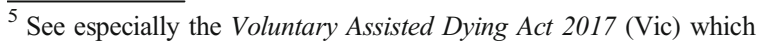
has 68 statutory safeguards. For further discussion see White et al. (2020). 
Parliament of Canada. December 17. https://www.parl. $\mathrm{ca} /$ LegisInfo/BillDetails.aspx ?billId $=10875380 \&$ Language $=$ E. Accessed 10 Jan 2021.

Nicol, J., and M. Tiedemann. 2020. Bill C-7: An Act to amend the Criminal Code (Medical Assistance in Dying) (Legislative Summary). Library of Parliament: Publication No.43-1-C7-E.
White, B., K. Del Villar, E. Close, and L. Willmott. 2020. Does the Voluntary Assisted Dying Act 2017 (Vic) reflect its stated policy goals? UNSW Law Journal 43(2): 417.

Publisher's note Springer Nature remains neutral with regard to jurisdictional claims in published maps and institutional affiliations. 